\title{
Digital X-ray imaging using matrix detectors and composite screens
}

\author{
E.F.Voronkin \\ Institute for Scintillation Materials, STC "Institute for Single Crystals", \\ National Academy of Sciences of Ukraine, \\ 60 Lenin Ave., 61001 Kharkiv, Ukraine
}

\author{
Received September 25, 2013
}

\begin{abstract}
In the paper it has been shown the possibility to use large area dispersed scintillators based on ZnSe:Al scintillation screens having a maximum luminescence in photoabsorption of zinc selenide instead of X-ray film for defectoscopy of metal products. Experimental data on influence of X-ray absorption by the samples using scintillation screens based on zinc selenide chalcogenide scintillator and ERS-S-2A on the thickness of the sample at an acceleration voltage in $\mathrm{kV}$ are reported. Prospects of using the zinc selenide composite screens in imaging of biological objects are shown, which proves the possibility of using these screens in tomographic medical systems.
\end{abstract}

Показана возможность применения для дефектоскопии изделий из металла, взамен рентгеновской пленки, дисперсных сцинтилляторов большой площади на основе сцинтилляционных экранов ZnSe:Al, обладающих максимумом люминесценции в области фотопоглощения селенида цинка. Приведены экспериментальные данные поглощения рентгеновского излучения сцинтилляционных экранов на основе халькогенидного сцинтиллятора селенида цинка и ЭРС-C-2A от его толщины при ускоряющем напряжении в кВ. Показана перспективность применения композитных экранов из селенида цинка при визуализации биологических объектов, что свидетельствует о возможности использования этих экранов в томографических медицинских системах.

\footnotetext{
Цифрова рентгенографія із застосуванням матричних детекторів $i$ композитних екранів. Є.Ф.Воронкін.

Показано можливість використання у дефектоскопії виробів з металу, замість рентгенівської плівки, композитних сцинтиляторів великої площі на основі ZnSe:Al, що мають максимум люмінісценції в області фотопоглинання селеніду цинка. Приведено експериментальні дані поглинання рентгенівського випромінювання сцинтилляційних екранів на основі халькогенідного сцинтилятора селеніду цинку та ЭРС-С-2А от його товщини при прискорюючій напрузі кВ. Показано можливість використання композитних екранів з селеніду цинку у візуалізації біологічних об’єктів, що свідчить про можливості використання цих екранів у томографічних медичниих системах.
}

\section{Introduction}

The term of "Digital X-ray imaging" (fluorography) refers to the methods in which image is formed and processed exclusively by computers [1]. In devices of this type radiation relief is converted into a set of digital data. That is, on each unit of the analog image area the digital system will calculate the average optical density and fixes for it the necessary numeric values. Thus, an image in the form of digital matrix is obtained. The unit of the digital image area is a pixel having its own spatial coordinates on the matrix. Data medium contains information on the coordinates and the optical density of each pixel. 
Digital images in comparison with the analog film medium are much easier to study, process, and store [2]. Unlike the film ones, digital fluorographs operate in real time and provide images almost instantly. In case there is a big quantity of images, they can be archived that allows reviewing the disease progress or regression at any time. The digital photos can be sent by e-mail without any loss of the image quality (256 gray shades) to consult specialists $[4,5]$.

Several options for obtaining X-ray shadow image are practiced now. The main differences consist in the options of obtaining a picture - from a flat scintillation screen or by scanning with a linear detector - X-ray scanner. Their difference consists in the time frame of the research and algorithms of photodetectors signal processing. Scanning matrix fluorographs illuminate the object layer by layer forming the overall picture on the monitor. Matrix fluorographs carry out the exposure in centiseconds which is very important when a patient can not hold his breath for some reason even for a short time. Instant chest photo by the matrix fluorograph has a very high quality since it is not affected by such "distraction" moments, giving false information, as:pulsing heart, aorta and major blood vessels motion.

The fundamental difference of the CCD detectors with X-ray screen is the formation of a shadow image using a system of lens (object glass) from the glowing screen dimensions $400 \mathrm{~mm}$ by $400 \mathrm{~mm}$. The system of lens and mirrors reduces the image to the size of the CCD matrix.

Systems with a flat screen are also used in defectosopy, where it is acceptable to use rather long time of the object exposure.

The X-ray scanners using detectors of scintillator-photodetector type are widely used in transport systems for screening the baggage of passengers, freights and at post offices. At present the various types of digital direct conversion panels based on polysilicon and amorphous selenium have developed, but they are mainly used in modern medical fluorographs to diagnose osteoporosis and cancer. This is due to the high cost of semiconductor panels and their lack of radiation hardness.

On the assumption of the mentioned above we can conclude that visualization of the internal structure of objects by means of scintillation detectors is an important and many sided task, and detectors parame- ters determine to a wide extent the quality of the images.

This paper presents comparative data of traditional and new types of composite scintillation screens based on chalcogenide oxysulfide and tungstate luminophores and evaluates the efficiency of their application in the digital X-ray imaging $[3,6]$.

\section{Distinctive features of scanning and screening systems}

As indicated above, the difference lies in $\mathrm{X}$-ray detectors used in the devices. If we take a linear X-ray detector of about $400 \mathrm{~mm}^{2}$ long moving which along the patient's body simultaneously with fan-shaped X-ray irradiation, the area of $400 \times 400 \mathrm{~mm}$ and more can be examined. Such scanning systems have advantages and disadvantages such as

Advantages:

- Possibility to scan the long objects;

- Possibility of using the multi-energy detectors that allows distinguishing materials with different atomic number (organic and inorganic composition);

- Possibility of obtaining the three-dimensional display of the object when helical scanning (used in tomography);

- High contrast sensitivity due to the proximity of the scintillator to the photodetector.

Disadvantages:

- Complexity of mathematical signal processing for the reconstruction of the $\mathrm{X}$-ray shadow display;

- High requirements to the mechanical scanning devices for vibration and uniformity of displacement;

- Diffused display of the moving objects, for example, while examining a patient's heart.

Scintillation crystals or ceramics are most commonly used in the scanning systems detectors. Their characteristics presented in Table 1 will be considered below.

Low exposure time, centiseconds, is characteristic for the screen systems. This is a mandatory requirement of medical workers while examining thoracic organs. Even in the case when a patient holds his breath correctly, there are still the aorta, the heart and major vessels pulsing. Therefore, for the digital fluorography it is extremely important to take an "instant" image with a clear boundary of vessels and the heart. The most important elements of the screen $\mathrm{X}$-ray imaging systems are the X-ray screen itself and the photodetector. The quality of 
Table 1. Comparative parameters of X-ray scintillators

\begin{tabular}{|c|c|c|c|c|c|c|c|}
\hline Parameter & CsI(TI) & $\mathrm{CdWO}_{4}$ & $\mathrm{ZnWO}_{4}$ & $\begin{array}{l}\mathrm{Gd}_{2} \mathrm{O}_{2} \mathrm{~S}: \\
\mathrm{Pr}, \mathrm{Ce}, \mathrm{F}\end{array}$ & $\mathrm{Gd}_{2} \mathrm{O}_{2} \mathrm{~S}: \mathrm{Tb}$ & $\begin{array}{c}\mathrm{Lu}_{2} \mathrm{SiO}_{5}: \\
\mathrm{Ce}(\mathrm{LSO}: \mathrm{Ce})\end{array}$ & ZnSe:Al \\
\hline $\begin{array}{c}\text { Absolute light yield, } \\
\text { phot./MeV at } \\
662 \mathrm{keV}\left(\cdot 10^{3}\right) \\
\end{array}$ & 56 & 20 & 14 & 35 & 60 & 30 & 60 \\
\hline Density, $\mathrm{g} / \mathrm{cm}^{3}$ & 4.51 & 8.28 & 7.87 & 7.3 & 7.3 & 7.41 & 5.42 \\
\hline$Z_{\text {eff }}$ & 54 & 66 & 61 & 62 & 62 & 66.4 & 33 \\
\hline$T_{\text {melting }},{ }^{\circ} \mathrm{C}$ & 894 & 1325 & 1200 & Decomp. & Decomp. & 2150 & 1520 \\
\hline Refractive index & 1.79 & 2.3 & 2.2 & 2.2 & 1.82 & 2.5 & \\
\hline$\lambda_{\max }, \mathrm{nm}$ & 550 & 495 & 490 & 520 & 550 & 420 & 610 \\
\hline $\begin{array}{l}\text { Extinction } \\
\text { coefficient of own } \\
\text { radiation, } \mathrm{cm}^{-1}\end{array}$ & 0.05 & 0.03 & 0.05 & 1 & 0.6 & 0.04 & 0.3 \\
\hline $\begin{array}{l}\text { Radiation resistance, } \\
\text { rads }\end{array}$ & $10^{6}$ & $10^{6}$ & $10^{5}$ & $10^{7}$ & $10^{7}$ & $10^{8}$ & $10^{7}$ \\
\hline Decay time, ms & 6 & 5 & 3 & 4 & 600 & 0.04 & 2 \\
\hline $\begin{array}{c}\text { Afterglow, \% } \\
\text { after } 3 \mathrm{~ms}\end{array}$ & 20 & 0.1 & 0.2 & 0.1 & 1 & 0.5 & 0.1 \\
\hline
\end{tabular}

X-ray display on the screen depends not so much on the resolution of the $\mathrm{X}$-ray screen and the photodetector as on the balance of three parameters: conversion efficiency of the luminophore, granularity or particle size of the screen, dynamic range (gradation resolution - number of gray levels) of the screen and the photodetector.

Theoretically, the greater is the number of pixels of the photodetector, the higher is the resolution. However, it is important to reduce the radiation dose for the patient. It is possible to reduce the dose without losing the image dynamic range (number of gradations of the gray shades) due to high-quality optics and complex image processing algorithm. Cheaper (i.e., of worse quality) optics makes it impossible to reduce the dose for the patient and not lose the dynamic range and, as a consequence, quality of the image goes down in spite of the higher resolution.

In speaking of fluorography of thoracic organs it is necessary to keep in mind that for their X-ray display it is much more important to provide the possibility to reproduce more half-lights - gradations of the gray shades (i.e., low-contrast ill-defined entities about $1 \mathrm{~mm}$ diameter) than the possibility to reproduce the small contrast details.

\section{Comparative characteristics of luminophores}

Luminescence intensity of the screen depends on the quantum yield of the scintillator, thickness of the absorbing layer and transparency of the screen to its own radiation. To increase the light yield of the screen it is necessary to use the layer thickness of scintillation particles optimal in terms of absorption efficiency of X-rays quantum and light signal yield on the photodetector. To ensure the high spatial resolution the scintillator should have high contrast of the shaded image and photodetector - the required spatial resolution and maximum sensitivity in the maximum luminescence range of the luminophore. Table 1 shows comparative parameters of traditional and new types of luminophores used in the X-ray detectors. These parameters provide a rough idea of the $\mathrm{X}$-rays quantum (density and $Z_{\text {eff }}$ ) absorbency luminosity (light yield, $\lambda_{\max }$ ), light-collection conditions (refractive index and extinction coefficient of own radiation), radiation resistance to X-rays and scintillation signal kinetics (decay time and afterglow level after 3 milliseconds after X-ray pulse termination).

For technical defectoscopy where high fluences of high-energy X-rays quantum are used, it is necessary to apply high density luminophores with high atomic number, such as $\mathrm{CdWO}_{4}, \mathrm{ZnWO}_{4}, \mathrm{Lu}_{2} \mathrm{SiO}_{5}: \mathrm{Ce}$, 
Table 2. Fine ZnSe:Al screen. Material of X-raying - aluminum

\begin{tabular}{|c|c|c|c|c|c|c|}
\hline \multirow[t]{2}{*}{$\begin{array}{l}\text { Acceleration } \\
\text { voltage, } \mathrm{kV}\end{array}$} & \multicolumn{6}{|c|}{$\begin{array}{l}\text { Control sensitivity, }(\%) \\
\text { Thickness of the controlled object }+ \text { thickness of sensitivity indicator }(2 \mathrm{~mm}), \mathrm{mm}\end{array}$} \\
\hline & 5 & 8 & 11 & 14 & 19 & 24 \\
\hline 30 & 12 & & & & & \\
\hline 40 & 4 & 6.25 & 18 & & & \\
\hline 50 & 2 & 3.75 & 4.5 & 4.3 & & \\
\hline 60 & 2 & 2.5 & 2.7 & 2.9 & 10 & \\
\hline 70 & 1.5 & 1.5 & 1.8 & 2.1 & 3.1 & 1.7 \\
\hline 80 & 1.5 & 1.25 & 0.9 & 1.4 & 1.6 & 1.7 \\
\hline 90 & 1.5 & 1.25 & 0.9 & 0.7 & 1 & 1.3 \\
\hline 100 & & 2.5 & 0.9 & 0.7 & 1 & 1.7 \\
\hline 110 & & 3.75 & 0.9 & 0.6 & 0.5 & 2 \\
\hline 120 & & & 0.9 & 0.6 & 0.5 & 2 \\
\hline 130 & & & 1.8 & 1.4 & 1 & \\
\hline
\end{tabular}

$\mathrm{Gd}_{2} \mathrm{O}_{2} \mathrm{~S}: \mathrm{Tb}$ (Table 2) [7]. For several luminophores which do not decompose when melting $\left(\mathrm{CdWO}_{4}, \mathrm{ZnWO}_{4}, \mathrm{Lu}_{2} \mathrm{SiO}_{5}: \mathrm{Ce}\right)$, it is possible to obtain screens in the form of crystals. Oxysulfides are used in the form of monodisperse powder distributed in a polymeric binder or in the form of ceramics. The scintillation substances listed in the table are characterized by high radiation resistance, satisfactory kinetic parameters (except $\mathrm{Gd}_{2} \mathrm{O}_{2} \mathrm{~S}: \mathrm{Tb}$ ), satisfactory agreement with the sensitivity spectrum of silicon photodetectors for $\mathrm{ZnSe}: \mathrm{Al}, \mathrm{Gd}_{2} \mathrm{O}_{2} \mathrm{~S}: \mathrm{Tb}$, $\mathrm{Gd}_{2} \mathrm{O}_{2} \mathrm{~S}: \mathrm{Pr}, \mathrm{Ce}$.

\section{Special aspects of applying composite scintillators in digital $X$-ray imaging}

Necessity of objects defectoscopy in the real time using high-resolution video recording and development of multi-energy technique for recording the shaded images created new requirements to the scintillators parameters. This is tightening of requirements to the luminescence kinetics, symbate character of light yield changes with temperature, radiation resistance of scintillators not below $10^{6}$ rads. In this case the energy dependence of scintillators light yield depends significantly on the thickness of a sample, the effective atomic number $\left(Z_{\text {eff }}\right)$ and the transparency to its own radiation.

Fig. 1 shows dependence of the light yield of ceramic and crystal scintillators on anode voltage. At $50 \mathrm{kV} Z \mathrm{nSe} 0.6 \mathrm{~mm}$ thick has the maximum signal. With an increase of anode voltage from $50 \mathrm{kV}$ to $130 \mathrm{kV}$ the sample light yield is not substantially

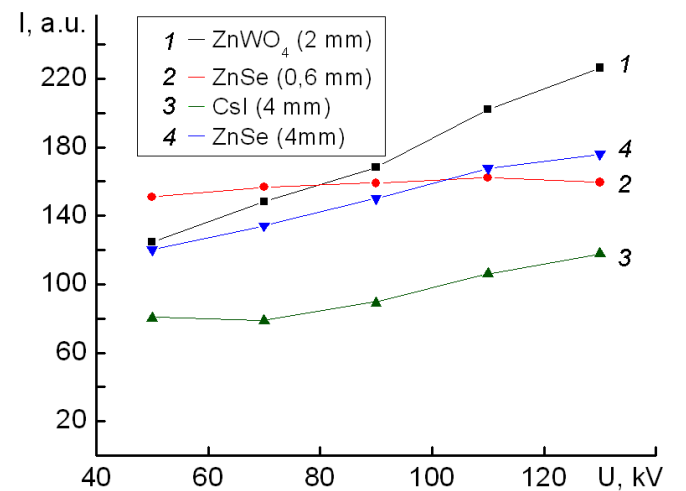

Fig. 1. Light yield of GOS ceramics, ZnSe:Al and $\mathrm{CsI}(\mathrm{TI})$ measured at constant current of $\mathrm{X}$-ray emitter and varying anode voltage from 50 to $130 \mathrm{kV}$.

changed due to the absorption therein of a low-energy part of the X-ray signal only.

We have carried out comparative tests of different samples of scintillation screens manufactured by us and of industrial production. The screens were tested in the range of radiation energy (from $30 \mathrm{keV}$ to $120 \mathrm{keV}$ ). For comparison in the same conditions and for the same thickness the testing of ERS-S-2A medical screen was carried out. Sensitivity of radiation monitoring was determined by the sensitivity groove indicator for different thicknesses and radiation energies. As the X-ray source RAP 150/300 X-ray apparatus with a focal spot of $3.2 \mathrm{~mm}$ was used, which is not suitable for $\mathrm{X}$-ray screening. The results are obtained on our equipment which is not commercial with staff video processor for statistical processing of the X-ray shaded image by means of 


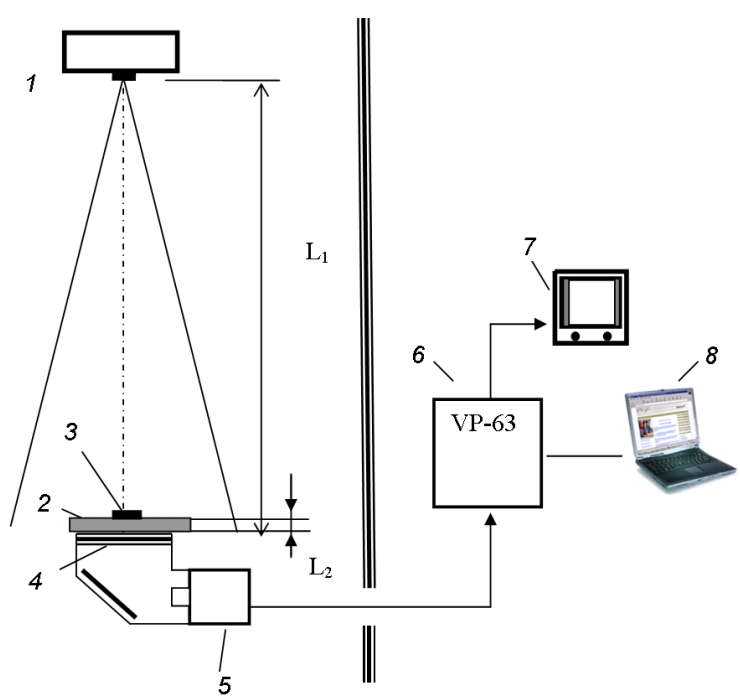

Fig. 2. Scheme and hardware for the study of X-ray screens parameters. 1 - X-ray source; 2 - aluminum plate (thickness varies); 3 indicator of $\mathrm{Al}$ sensitivity No.1; 4 - X-ray optical converter (screen); 5 - television transmitting camera; 6 - video processor; 7 TV monitor; 8 - computer unit for processing and archiving X-ray images.

storage for filtering fluctuation noises of the X-ray television channel. Furthermore, the video processor allows documenting the $\mathrm{X}$-ray images electronically. According to test results and obtained images of the test objects we can draw conclusions as to the performance of the screens.

As the below test results shown the most efficient converter of the shaded X-ray image into the visible one is ZnSe:Al (the first fine scintillation screen). In the second place is the efficiency of ERS-S-2A screen with a considerable underrun.

The second screen dithers the image, i.e. does not provide resolution. This is associated with a high rate of the screen dispersion coefficient that can easily be seen in the X-ray images of sensitivity reference sample with the same parameters of X-ray examination.

The both X-ray images were obtained under identical conditions of X-ray examination. Fig. 3 clearly shows the outlines of the sensitivity indicator and 6 grooves. Furthermore, the image clearly represents visible spots of oxides on metal that proves the high sensitivity of the screen to small changes in the density of the tested object.

In Fig. 4 we can see the dithered outline of the indicator and hardly visible grooves. This is due to the blurring of the shaded $\mathrm{X}$-ray image in the structure of the screen itself. In addition, the structure of the

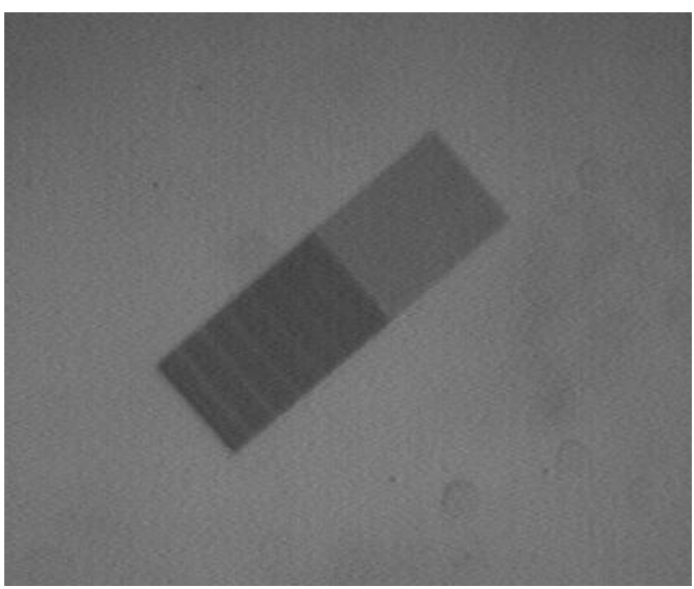

Fig. 3. X-ray image of sensitivity indicator on aluminum $H=3 \mathrm{~mm}$ obtained using ZnSe:Al screen.

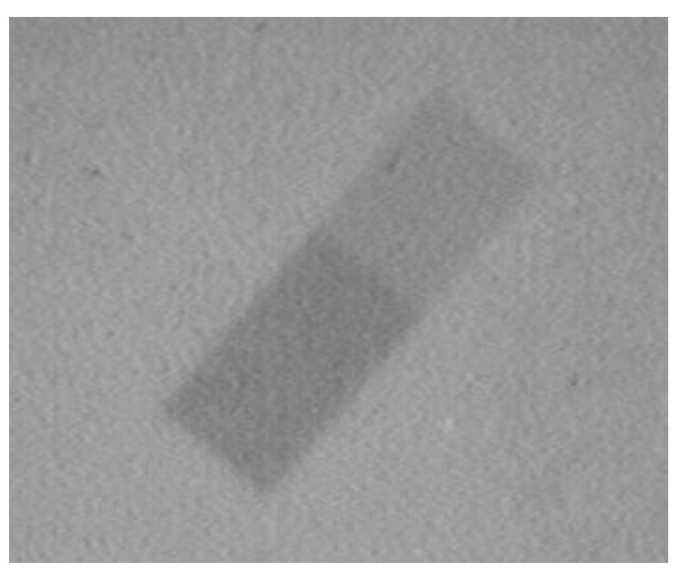

Fig. 4. X-ray image of sensitivity indicator on aluminum $H=3 \mathrm{~mm}$ obtained using the second ERS-S-2A medical screen.

screen is more evident. The screen glows under the X-rays, but does not provide sufficient resolution and control sensitivity.

Below it is shown dependence of the sensitivity of radiation monitoring of aluminum products by groove indicator for different thickness of the material and different energies of ionizing radiation while using two types of screens: ZnSe:Al and medical ERS-S-2A .

These characteristics allow estimating the efficiency of conversion of the X-ray shaded image into the visible one by the screens as well as to determine the operating energy range in which the screen allows obtaining the best sensitivity of radiation quality control due to insufficient brightness of the screen and structural noises of the screen and CCD-matrix still appear very significant. The upper limit of the dynamic range is determined by the 
Table 3. Medical ERS-S-2A screen. Material of X-raying - aluminum.

\begin{tabular}{|c|c|c|c|c|c|}
\hline \multirow[t]{2}{*}{$\begin{array}{l}\text { Acceleration } \\
\text { voltage, } \mathrm{kV}\end{array}$} & \multicolumn{5}{|c|}{$\begin{array}{l}\text { Control sensitivity, }(\%) \\
\text { Thickness of the controlled object }\end{array}$} \\
\hline & 5 & 8 & 11 & 14 & 19 \\
\hline 30 & 12 & & & & \\
\hline 40 & 6 & 25 & 18 & & \\
\hline 50 & 5 & 4 & 3.6 & 14 & \\
\hline 60 & 5 & 3 & 3.6 & 2.1 & 10 \\
\hline 70 & 4 & 3 & 2.7 & 1.4 & 10 \\
\hline 80 & 3 & 2.5 & 1.8 & 2.1 & 10 \\
\hline 90 & 2 & 2.5 & 1.8 & 2.1 & 10 \\
\hline 100 & 4 & 2.5 & 1.8 & 2.1 & 10 \\
\hline 110 & & 2 & 1.8 & 1.8 & 3.2 \\
\hline 120 & & & 1.8 & 1.4 & 3.2 \\
\hline 130 & & & & 1.8 & 3.2 \\
\hline
\end{tabular}

saturation of the screen, i.e. with increasing the radiation energy the brightness of glowing does not increase which leads to a decrease of the contrast and loss of the image elements with a small density difference. In other words, the smallest grooves of the sensitivity indicator begin to disappear on the X-ray image.

In Fig. 5 for ZnSe:Al screen 5 grooves of the indicator No.1 are clearly identifiable that corresponds to sensitivity of $3.3 \%$. On the steel $9 \mathrm{~mm}$ thick at the voltage of $140 \mathrm{keV} 4$ grooves of the indicator No.1 are visible that corresponds to sensitivity of $2.7 \%$.

When the X-ray studies of biological objects it is necessary to obtain information about the morphology (skeleton bones, soft tissue, blood vessels). The main requirements to the image are high spatial resolution, high contrast in a wide dynamic

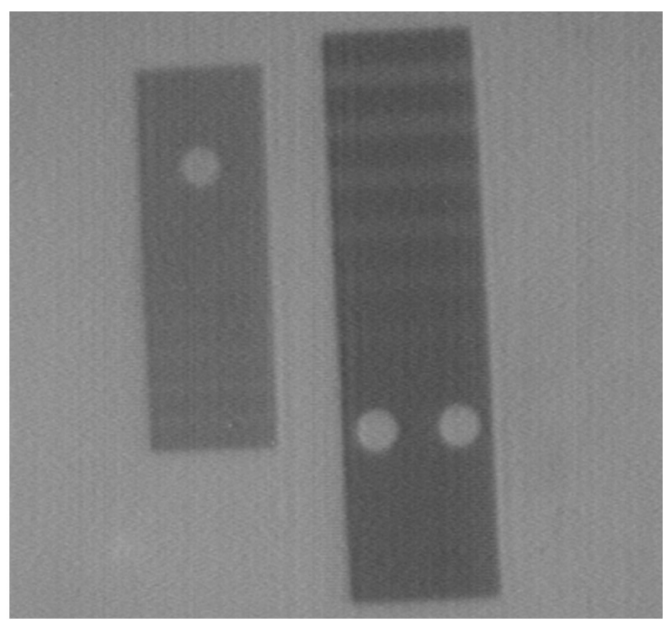

Fig. 5. X-ray image of sensitivity indicators No. 1 and No. 2 of steel $4 \mathrm{~mm}$ thick at X-ray energy of $140 \mathrm{keV}$.

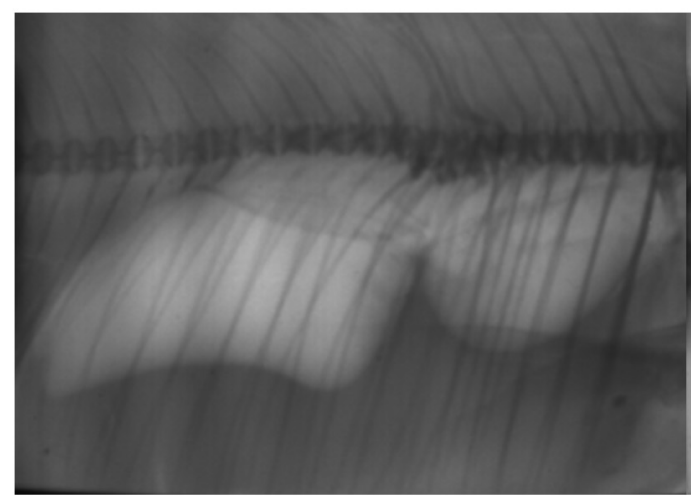

a)

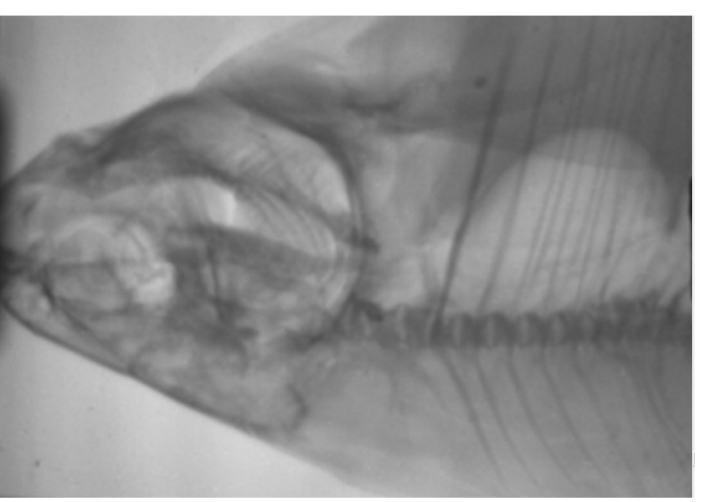

b)

Fig. 6. Image of the biological object obtained using ZnSe:Al screen. 
range and minimum radiation exposure to the patient.

The screen made of fine-grained scintillation zinc selenide powder [8-10] (Fig. 6) has good sensitivity, resolution and efficiency of conversion of the X-ray shaded image into the visible one. This screen is especially efficient for imaging the biological objects and as it can be seen in Fig. 6, allows recognizing contrastively even the tissue of fish float. The optimum energy range for such screen is $30-50 \mathrm{keV}$.

\section{Conclusions}

The samples of fine X-ray screens based on semiconductor ZnSe:Al crystals working in the energy range of $50 \div 140 \mathrm{keV}$ for application in radiation defectoscopy systems were produced and tested. The experiments showed the high resolution when testing metal indication samples, the high resolution and contrast sensitivity of the screen.

Spectral characteristic of the screen radiation combines well with the spectral sensitivity characteristic of the CCD and CMOS image sensors used to convert a shaded image into a video signal.

On the sample of aluminum $10 \mathrm{~mm}$ thick with groove penetrometer the control sensi- tivity of $1 \%$ was obtained which is close to sensitivity obtained by means of film technology.

The prospects of using zinc selenide composite screens in imaging of biological objects are shown, which proves the possibility of using these screens in tomographic medical systems.

\section{References}

1. Yu.G.Ryudiger, Med. Dev., No.6, 32 (2004).

2. W.E van Eijk Carel, Phys. in Med. and Biol., No.47, 85 (2002).

3. G.V.Ananieva, E.I.Gorokhova, V.A.Demidenko, Opt. J., No.72, 68 (2005).

4. The Physics of Medical Imaging, ed. by S.Webb, CRC Press, Bristol (1988).

5. Yu.F.Poloyko, News of X-ray Diagnostics, $\mathbf{1}$, 31 (1998).

6. M.Nikl, Meas. Sci. Technol., 17, R37 (2006).

7. E.Voronkin, V.Litichevskyi, S.Galkin, O.Lalaiants, Functional Materials, 18, 391 (2011).

8. E.F.Voronkin, S.N.Galkin, O.A.Sosnitskaya et al., Ukrainian Patent No.101234.

9. E.F.Voronkin, S.N.Galkin, A.I.Lalaiants et al., Ukrainian Patent No.101724.

10. E.F.Voronkin, S.N.Galkin, V.D.Ryzhikov et al., Ukrainian Patent No.92286. 